\title{
Subjective experiences of employment equity in South African organisations
}

\begin{tabular}{|c|c|}
\hline \multicolumn{2}{|c|}{$\begin{array}{l}\text { Authors: } \\
\text { Rudolf M. Oosthuizen }{ }^{1} \text { (D) } \\
\text { Louise Tonelli }{ }^{1} \text { (D) } \\
\text { Claude-Hélène Mayer }{ }^{2} \text { (D) }\end{array}$} \\
\hline \multicolumn{2}{|c|}{$\begin{array}{l}\text { Affiliations: } \\
{ }^{1} \text { Department of Industrial } \\
\text { and Organisational } \\
\text { Psychology, University of } \\
\text { South Africa, Pretoria, } \\
\text { South Africa }\end{array}$} \\
\hline \multicolumn{2}{|c|}{$\begin{array}{l}{ }^{2} \text { Department of } \\
\text { Management, Rhodes } \\
\text { University, Grahamstown, } \\
\text { South Africa }\end{array}$} \\
\hline \multicolumn{2}{|c|}{$\begin{array}{l}\text { Corresponding author: } \\
\text { Rudolf Oosthuizen, } \\
\text { oosthrm@unisa.ac.za }\end{array}$} \\
\hline \multicolumn{2}{|c|}{$\begin{array}{l}\text { Dates: } \\
\text { Received: } 04 \text { May } 2018 \\
\text { Accepted: } 01 \text { Oct. } 2018 \\
\text { Published: } 08 \text { Apr. } 2019\end{array}$} \\
\hline \multicolumn{2}{|c|}{$\begin{array}{l}\text { How to cite this article: } \\
\text { Oosthuizen, R.M., Tonelli, L., } \\
\text { \& Mayer, C-H. (2019). } \\
\text { Subjective experiences of } \\
\text { employment equity in South } \\
\text { African organisations. SA } \\
\text { Journal of Human Resource } \\
\text { Management/SA Tydskrif vir } \\
\text { Menslikehulpbronbestuur, } \\
\text { 17(0), a1074. https://doi. } \\
\text { org/10.4102/sajhrm. } \\
\text { v17i0.1074 }\end{array}$} \\
\hline \multicolumn{2}{|c|}{$\begin{array}{l}\text { Copyright: } \\
\text { (C) 2019. The Authors. } \\
\text { Licensee: AOSIS. This } \\
\text { is licensed under the } \\
\text { Creative Commons } \\
\text { Attribution License. }\end{array}$} \\
\hline \multicolumn{2}{|l|}{ Read online: } \\
\hline 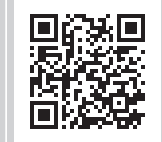 & $\begin{array}{l}\text { Scan this QR } \\
\text { code with your } \\
\text { smart phone or } \\
\text { mobile device } \\
\text { to read online. }\end{array}$ \\
\hline
\end{tabular}

Orientation: This article explores employees' subjective experiences of employment equity (EE) within South African organisational contexts, adding diverse and in-depth insights to the post-apartheid EE discourse.

Research purpose: The purpose is to hear the voices of employees of different social-cultural, racial and gender backgrounds on the experiences of EE in contemporary South African organisations.

Motivation for the study: Research suggests that South African organisations are pressurised to redress past racial inequality. Understanding employees' subjective experiences of EE adds value to the debate and provides the reader with an in-depth contemporary image of EE in post-apartheid South African organisations.

Research approach/design and method: A hermeneutic phenomenological approach, within the qualitative interpretive paradigm, yielded in-depth, rich and detailed descriptions of employees' experiences of EE in both the private and public sectors of the South African workplace.

Main findings: Findings show five themes that are associated with experiences of EE within South African organisations. This study highlights differences of experiences regarding EE plans and processes based on racial background, gender and age, as well as on historical socio-cultural and racial classifications of being a member of advantaged and disadvantaged groups. The following findings are highlighted: the insight into the experiences of EE from the perspectives of the 'born-frees' (the differences in experiences of different age groups of employees) and the experienced discrimination of black male and female employees regarding race and the experiences of gender-based discrimination being described by black and white male employees.

Practical/managerial implications: Findings show the focus of experiences of EE, the conflicting issues and what South African organisations need to focus on in terms of human resources management (HRM) and the development of employee relations across racial and gender divides. It shows which topics need to be addressed in employee development and training programmes to manage diversity constructively and effectively.

Contribution/value-add: The findings can be used by human resources managers to: (1) monitor the progress towards EE competently and vigorously, (2) create awareness and communication within individuals, organisations and society regarding EE, (3) create best practices in order to benefit from EE (members of all racial, gender, cultural groups), (4) create a discourse on humanistic and reflexive HRM, and(5) implement consulting, training and development programmes in organisations that are strategically, sustainably and long-term orientated.

Keywords: affirmative action; employment equity; diversity management; subjective experiences; post-apartheid South Africa.

\section{Introduction}

Organisations in South Africa are the key players in transforming the society on economic, political, structural, cultural and individual levels (Cloete, Bunting, \& Maassen, 2015). They are implementers of transformation with regard to employment equity (EE) and affirmative action (AA) to turn workplaces into democratic spaces of equality and equity. During apartheid, organisations were built up on racial and gender divides and promoted racial segregation while they are contemporarily legally bound to ensure diversity and inclusion through EE plans (Council for Higher Education [CHE], 2015).

Employment equity is defined as the employment of individuals in a fair and non-biased manner, thus to promote equal opportunity by eliminating discrimination in all employment policies and 
practices (Bendix, 2010, p. 145). Affirmative action refers to programmes designed to ensure the proportional representation of employees to undo the results of past discrimination. However, the latter definition may be viewed as problematic, because it does not explicitly acknowledge the assumption that those being considered for proportional representation are all equally qualified for certain positions (Saha, O'Donnell, Patel, \& Heneghan, 2008). Further, the terms 'employment equity' and 'affirmative action' are used interchangeably, although they are two different but related concepts (Mason, Williams, \& Cranner, 2009; Portnoi, 2003).

Since 1994, the South African government has provided revised legislative frameworks for organisations (Dingindawo, Nwafor, Mutshaeni, Mudzielwana, \& Mulovhedzi, 2016). One of the major strategic objectives is to ensure that organisations actively participate in eradicating discriminatory policies and practices that have been transferred from the past societal system (Van der Westhuizen, 2015). These policies and practices require active transformation to reflect the new democratic dispensation principles that are based on recognition and implementation of individual human rights in mind and practice (Ebrahim, 2018).

The Employment Equity Act 55 of 1998 (EEA) (Government Gazette, 2014) defines the designated recipients of EE opportunities as black ${ }^{1}$ employees, women and the physically challenged. The EEA demands that both public and private employers meet equity targets within their workplaces and report on the progress of meeting these targets (Sebola \& Khalo, 2010)

Since the implementation of the EEA (Basson, 2017), changes towards a more inclusive, diverse and democratic workforce have been implemented (Moraka \& Jansen van Rensburg, 2015). However, these changes seem to be rather 'on the surface' in terms of organisational changes and adjustment to legislative requirements (Herman, 2017). Organisations are required by law to present EE reports on a regular basis (Moraka \& Jansen van Rensburg, 2015); however, transformation seems to be non-existent in post-apartheid South Africa (Zulu \& Parumasur, 2009). Larger organisations fail to implement demographic representation (Surtee \& Hall, 2009) and racial quotas do not match the societal demographic profile (Mayer \& Barnard, 2015). A strong debate on colonialism, apartheid, postcolonialism and transformation has opened (Masombuka, 2016) a slow and steady change towards EE (Breetzke \& Hedding, 2016). The question of how to address EE stays vibrant (Louw, 2015a).

On a macro-level, AA programmes have been implemented and EEA and black economic empowerment (BEE) are dominant pieces of legislation passed by the democratic parliament to enact equity in the South African workplace (EEA, 1998). While the former focuses only on EE, the latter is more comprehensive and includes ownership and management targets for black individuals (Burger, Jafta, \& von Fintel, 2016). On the meso-level, organisations are requested to address EE on a daily basis (Hills, 2015) and change past racial inequalities. They are bound to employment according to racial quota to ensure the proportional representation of employees (Reuben \& Bobat, 2014). Organisations have to deal with the complexities and failures of AA and EE practices (Burger et al., 2016). On a micro-level, individuals working within organisations respond to EE (Lee, 2016). All three levels are interrelated and correspond with each other.

\section{Employment equity in South Africa}

It is likely that future employment relations in organisations will continue to be extensively influenced by EE and AA developments in South Africa. The course of action for AA, as set out in the EEA, continues to have far-reaching effects on employment relations practice. The Ministry of Labour continues to confirm the government's commitment to rectifying racial and gender imbalances in the workplace and to promote equity at all levels in the world of work (Timothy, 2013). In this vein, Section 15(1) of the EEA describes AA as:

measures designed to ensure that suitably qualified people from designated groups have equal employment opportunities and are equitably represented in all occupational categories and levels in the workplace of a designated employer. (Nel, Kisten, Swanepoel, Erasmus, \& Poisat, 2016)

However, as a contemporary issue, legislative mechanisms alone will not achieve EE in South Africa. Employment relation departments can influence the situation by means of effective training and development of people (Warnich, Carell, Elbert, \& Hatfield, 2015). Employment relation departments will also need to execute special programmes, such as black advancement, which should include literacy training of illiterate workers, support for quality education for workers and family members and, in communities where the organisation operates, mentorship and targeted recruitment programmes to achieve equality in organisations and ultimately in society (Nel et al., 2016).

Another aspect concerning addressing imbalances is that making correct AA appointments enables organisations to enjoy new streams of business, while those that have not done so experience the frustrations of exclusion from government and other tenders based on their lack of EE. Nicoll $(2006$, p. 6) cautions that the international concept of AA is ultimately to protect the minorities. In South African imbalances created by past practices have to be redressed, to ensure that the previously disadvantaged majority can be empowered. Once the balance has been redressed, legislation has to protect the rights of minorities such as white people, mixed race, Asians, females and disabled people. There are cases of EE targets already being achieved. In some cases, management now focuses on redressing the imbalance with, for instance, an exceptionally large black representation ( $\mathrm{Nel}$ et al., 2016).

Also, negative belief systems of employees towards EE policies seem to hinder its effectiveness in organisations 
(Ivona \& Lance, 2014). This is true for both non-beneficiaries (men) and beneficiaries (women), who react negatively to EE policies in terms of threatened self-image (Ivona \& Lance, 2014). Those least likely to experience a self-image threat when faced with a gender-based EE policy are the most likely to show positive reactions to EE policies, and both men and women react more favourably to EE policies when self-image threats are mitigated through a self-affirmation task (Ivona \& Lance, 2014).

Beneficiaries of EE plans fear tokenism and marginalisation, being victims of white manipulation or being sold out, when appointed to designated positions (Stoffels, 2015). The 'stigmatisation' argument (Heilman, Block, \& Stathatos, 1997) shows that professional employees believe in individual merit and dislike the labels 'incompetent' and 'less qualified' associated with EE. White employees not only question the political and ethical legitimacy of EE but also fear retribution or revenge from members of previously disadvantaged groups, loss of standards, punitive taxation and limitation of their career opportunities (De Beer \& Radley, 2000; Leonard \& Grobler, 2006). In addition, EE is associated with racism, unfair treatment and reverse discrimination (Denton Vloeberghs, 2003; Ng \& Burke, 2004).

Despite the challenges, previously established racial inequalities need to be addressed (Coetzer, 2009) and EE, AA and BEE might contribute positively to this process (Op't Hoog, Siebers, \& Linde, 2010). According to Nel, Kisten, Swanepoel, Erasmus and Poisat (2008), the EEA 55 of 1998 as amended (Government Gazette, 2014) stipulates that employers may not refuse to reward individuals on the basis of the inputs employers may deem unfavourable. In addition to the role legislation plays in upholding principles of equity, there is the practice in organisations of promoting and rewarding people who bring value such as skills, expertise, training, technological know-how and sound managerial and interpersonal skills into organisations (Van Zyl, 2017).

Organisations may promote and reward skilled employees, while members of all groups experience prejudices in the workplace (Golele \& Rachidi, 2017). The EEA's intention is to regulate unjust and unfair discrimination; however, the implementation and practices are rather unsatisfactory (Fernandez, 2016). Critiques question whether business organisations can navigate stormy waters and how effective communication efforts in support of equitable change management strategies are managed (Oosthuizen \& Naidoo, 2010). Employment equity challenges are brought before South African courts and different approaches through which EE and AA should be applied result in confusion, controversy and fierce debate (e.g. South African Police Service I, II, III).

The discourse contains the idea of abolishing the EEA 55 of 1998 on a specific future date, which will give organisations the freedom to implement EE and AA voluntarily (Rautenbach, 2015) and to involve the entire workforce in this transformational initiative (Ebrahim, 2018). The facts of stereotyping racial groups and misunderstandings about EE intentions emphasise the need to address the socio-historical context in any related communication strategy (Leonard \& Grobler, 2006; Louw, 2015b).

\section{Individuals' experiences of employment equity and affirmative action in organisations}

Although EE and AA are methods applied to redress the injustices committed during apartheid, skilled employees are under the impression that they are 'carrying' those who lack the skills to perform the work required of them (Burger et al., 2016; Oosthuizen \& Naidoo, 2010). Generally, employees experience reverse discrimination and racism, lack of training and development, and victimisation (Oosthuizen \& Naidoo, 2010).

Nel, Kisten, Swanepoel, Erasmus and Poisat (2012, p. 2015) postulate that the principle of distribution on the basis of equity raises concern about (1) whether all parties agree that equity is the most reasonable and fair-minded basis for reward allocations, resource distributions and performance appraisals; (2) valued inputs and outputs and (3) effective and efficient implementation (Government Gazette, 2014). Lack of communication and shared understanding of EE, the white male dominated organisational culture, low leadership commitment, retention of black employees, the role of white fear and the lack of meaningful engagement of white male employees in EE implementation are major barriers to effective EE implementation (Booysen, 2007). Black women leaders feel double discriminated through gender and race and feel caught up in postcolonial struggles, discourses of power, dominance, inferiority and superiority (Mayer, 2017). Further, the lack of tapping into the potential of a diverse workforce is limited through EE (Maharaj, Ortlepp, \& Stacey, 2008) and effective succession planning is needed (Roman \& Mason, 2015).

\section{The aim and purpose of this article}

The Employment Equity Act and AA have been discussed extensively; however, the voices of individual employees across racial and gender divides have hardly been researched on a micro-level (Mayer, 2017). They might differ from the organisational aims to implement EE plans and employees might see the organisational roles as difficult (Zulu \& Parumasur, 2009). We argue that subjective voices from individuals of diverse cultural, racial, gender and age groups need to be heard to sustainably transform organisations and society.

\section{Research design}

The research design is based on the post-modernist premise that reality is defined by multiple truths and that perceptions, experiences and realities are socio-culturally constructed within a specific frame of time and space (Creswell, 2013). This study applies a qualitative research approach within the hermeneutic-phenomenological research paradigm (Creswell, 2013; Collis \& Hussey, 2014) to explore the subjective experiences of individuals' work 
lives and social worlds (Creswell, 2013; Hassan \& Ghauri, 2014). This perspective is orientated towards lived experiences to yield rich and detailed descriptions of EE (Creswell, 2013; Ramgoolam, 2005), thereby focusing on the Verstehen (understanding) of the lived experience (Dilthey, 2002). Phenomenology lends itself not only to description but to an interpretive process, where the researchers mediate between different meanings of the meaning of lived experiences (Creswell, 2013).

A hermeneutic approach to the multiple case study (Yin, 2009) allowed the researchers to analyse the data from the perspective of the researchers while emphasising the social and historical context within which it was produced (Clark \& Hogget, 2009, Grix, 2010). The researchers of this study looked further than simple hermeneutics, which concerns individuals' interpretations of themselves, such as the participants' interpretations of their experiences of EE, towards double hermeneutics, which implies a multilevel interpretation within a theoretical frame of reference. Double hermeneutics mitigates as far as possible the power relationships between researchers and participants through critical reflexivity of the data by the researchers, not to lose the voice of the participants themselves. Reflection in this context, is defined as interpretations by the researchers of EE interpretations of the participants themselves, in an attempt to gain an understanding of the participants' subjective experiences of EE (Clark \& Hogget, 2009).

\section{Research method}

A qualitative multiple case study was used as a research method towards an in-depth understanding of subjective experiences of EE towards identifying consistent patterns of behaviour and to possibly uncover new or divergent themes (Yin, 2009; Zach, 2006). The multiple case study consisted of 79 face-to-face semi-structured interviews.

\section{Research setting}

The study is based within South African public and private organisations' (see Table 1) specified financial turnovers requiring them to comply with EE legislation (Department of Labour, 2002; Government Gazette, 2014; Thomas, 2003).

\section{Entrée and establishing researcher roles}

Organisations from both the private and public sector that complied with EE legislation were approached by the three researchers and invited to participate. Permission was obtained from the organisations to conduct the research. The researchers introduced themselves and a trustful relationship was built.

\section{Sampling}

Eleven organisations took part in this study. Employees from these organisations were obtained through purposeful sampling strategies (Welman, Kruger, \& Mitchell, 2012), which were based on inclusion criteria, such as race, gender, language competency and general accessibility. Three separate organisations have been classified under the first heading in Table 1, 'human resources and private sector'.

\section{Data collection methods}

Data were collected over a period of a year, which consisted of 79 face-to-face semi-structured interviews of $30 \mathrm{~min}$ to $60 \mathrm{~min}$ each. Each participant conducted 4 to 23 interviews each with employees who had experience with EE (Kruger, 1988, p. 150). Interviews were conducted in English. Employees were assured of the confidentiality and ethical considerations were applied. The semi-structured interviews started with the questions: 'What is your personal story in terms of your experience of EE in the workplace?' This question was probed by means of elaboration and further explanation (Pietersen, 2007).

\section{Data analysis and interpretation}

Data were analysed as recommended in phenomenology studies (Clarke \& Hoggett, 2009; Creswell 2013) by applying the following steps: (1) the data were subjected to an initial, preliminary and holistic assessment, organising and reading through; (2) themes were generated; (3) data were coded, to describe the way in which the text was represented through inductive and deductive thinking; (4) the body of the text was broken down into meaningful pieces that were labelled; and (5) closer attention was paid to the subtleties and nuances of the meaning inherent in the data, through the 'double hermeneutics' abstracting beyond codes and themes by remaining within the hermeneutic characteristics

TABLE 1: Demographic breakdown of the sample by occupational category, race and gender.

\begin{tabular}{|c|c|c|c|c|c|c|c|c|c|}
\hline Organisation & $\begin{array}{c}\text { African } \\
\text { male }\end{array}$ & $\begin{array}{l}\text { African } \\
\text { female }\end{array}$ & $\begin{array}{c}\text { Mixed } \\
\text { race male }\end{array}$ & $\begin{array}{c}\text { Mixed } \\
\text { race female }\end{array}$ & $\begin{array}{c}\text { Indian } \\
\text { male }\end{array}$ & $\begin{array}{l}\text { Indian } \\
\text { female }\end{array}$ & $\begin{array}{l}\text { White } \\
\text { male }\end{array}$ & $\begin{array}{l}\text { White } \\
\text { female }\end{array}$ & Total \\
\hline Human resources/private sector & 2 & 9 & - & 1 & - & 2 & 8 & 1 & 23 \\
\hline Bank & 2 & 2 & 2 & 2 & 2 & 2 & 2 & 2 & 16 \\
\hline Short-term insurance & 1 & 1 & 1 & 1 & 1 & 1 & 1 & 1 & 8 \\
\hline Human resources/public sector & 1 & 1 & 1 & 1 & - & - & 1 & 1 & 6 \\
\hline Medical insurance & 3 & 1 & - & - & - & - & 2 & - & 6 \\
\hline Professionals/management & - & 1 & 1 & - & - & - & 4 & - & 6 \\
\hline Consulting/human resources ETDP Seta & 1 & 1 & - & - & - & - & 2 & 1 & 5 \\
\hline Motor industry & 1 & - & - & 1 & - & 1 & 2 & - & 5 \\
\hline Fast moving consumer goods & 2 & 1 & - & 1 & - & - & - & - & 4 \\
\hline Total & 13 & 17 & 5 & 7 & 3 & 6 & 22 & 6 & 79 \\
\hline
\end{tabular}

ETDP, education, training and development programme. 
of description, reduction and intentionality through a iterative process of sense-making of the data (Kafle, 2013). Interpreting the personal interpretations of $\mathrm{EE}$ of the participants by forming interpretations of the interpretations through reflexivity of the researchers (Clarke \& Hoggett, 2009). A data analysis aimed at developing knowledge of the participants' reality by safeguarding against the possibility of one person or group's rationality becoming another's reality, which could reinforce prejudice and injustice (Clarke \& Hoggett, 2009).

\section{Recording of data}

Data were recorded through field notes and audio recordings according to participant preferences. Audio recordings were transcribed verbatim and data are stored electronically for a period of 5 years in password-encrypted data files. Hard copy research projects were stored by the university under examination policies and procedures of the university with no access to the projects by the public.

\section{Strategies to ensure data quality and reporting}

Data quality was ensured through rich and detailed descriptions of employees' subjective experiences of EE through immersion in the data (Creswell 2013; Lincoln \& Guba, 1985). Credibility relied on the triangulation of different sources, methods and researchers where theories provide corroborating evidence (Creswell \& Plano Clark, 2011). The researchers triangulated the methods, primary and secondary resources used to establish credibility. Confirmability of data and document trail (Creswell, 2013) was promoted through intersubjective validation processes (Yin, 2009). The researchers used intersubjective validation processes to reflect on and discuss the data and their interpretations during several points in time of the data analysis and interpretation procedures. The rigour of the study was based on intersubjective validation processes and thick descriptions. Transferability of the findings to other settings was established through describing processes of research methodology, detailed findings and shared characteristics. Finally, this study does not focus on generatability per se but rather aims at providing an in-depth insight into the issue of research (Creswell, 2013; Lincoln \& Guba, 1985).

\section{Limitations of research}

The study was limited to a methodological approach exploring the subjective experiences of selected employees in
11 organisations, which may not be representative of the majority of South African organisations. The study was limited in terms of the sampling procedures and the defined aim without proclaiming generalisations.

\section{Ethical considerations}

Approval to conduct the study was obtained from the College of Economics and Management Sciences of the University of South Africa for ethical clearance in line with the policies of the university. Employees provided written consent and were informed about confidentiality and possibilities of withdrawal from the research participation.

\section{Results}

Findings led to five themes (see Table 2). Table 2 shows that the theme 'Race and gender reverse discrimination' was prevalent (85 statements), followed by statements on employees' 'Experiences of stereotyping' (61 statements), 'Organisational management of EE' (46 statements), 'Talent management' (35 statements) and 'Tokenism' (23 statements). Below, the findings have been presented in detail.

\section{Theme 1: Race, gender and reverse discrimination}

The majority of participants, across racial groups, highlighted 'race and gender reverse racism' and discriminative experiences in EE contexts. White male participants experienced EE as a racist system and compared their present experience to the experience of black participants during apartheid. A white male participant working in an insurance company commented:

'EE and AA, it was supposed to correct past inequities which is to make it equal for everyone in getting a job. If it is supposed to be so equal, why is it so difficult for a white male to get a job? Sounds to me like the white man is becoming the black man ... is that not discriminating against the white male now?' (Medical insurer, male, white)

A white middle-aged male participant based in the motor industry lacked comprehensibility in terms of understanding the logic behind retrenching skilled employees based on race:

'My dad was retrenched at his work after ten years of service purely based on the fact that he is white. So, my first impression is already a bad one. And I cannot understand why I must pay and suffer because of something that I wasn't part of.' (Motor Industry, white, male)

TABLE 2: Number of statements for each theme by organisation.

\begin{tabular}{|c|c|c|c|c|c|c|c|c|c|c|}
\hline Theme & $\begin{array}{l}\text { Banking } \\
\text { industry }\end{array}$ & $\begin{array}{c}\mathrm{HR} / \\
\text { private }\end{array}$ & $\begin{array}{c}\text { HR/ } \\
\text { public }\end{array}$ & $\begin{array}{c}\text { Professionals/ } \\
\text { management }\end{array}$ & $\begin{array}{c}\text { Short-term } \\
\text { insurance }\end{array}$ & $\begin{array}{l}\text { Medical } \\
\text { insurance }\end{array}$ & $\begin{array}{l}\text { Consulting/human } \\
\text { resources ETDP Seta }\end{array}$ & FMCG & $\begin{array}{c}\text { Motor } \\
\text { industry }\end{array}$ & Total \\
\hline Theme 1. Race and gender reverse discrimination & 16 & 21 & 7 & 10 & 1 & 15 & 0 & 3 & 12 & 85 \\
\hline Theme 2 . The born-frees & 11 & 20 & 5 & 16 & 2 & 3 & 1 & 0 & 3 & 61 \\
\hline Theme 3. Leading and managing diversity through $\mathrm{EE}$ & 9 & 4 & 10 & 6 & 11 & 4 & 0 & 0 & 2 & 46 \\
\hline Theme 4. Talent Management & 1 & 7 & 9 & 1 & 11 & 5 & 0 & 0 & 1 & 35 \\
\hline Theme 5. Tokenism & 1 & 6 & 2 & 2 & 0 & 8 & 0 & 0 & 4 & 23 \\
\hline Total & 38 & 58 & 33 & 35 & 25 & 35 & 1 & 3 & 22 & 250 \\
\hline
\end{tabular}

EE, employment equity; ETDP, education, training and development programme; FMCG, fast moving consumer goods. 
This male participant rejected taking collective responsibility for historical events as a member of the white group and denied his personal accountability. He did not favour EE because it does not resolve the encountered workplace problems. White male participants felt threatened by discrimination and ascribed the South African brain drain and experts leaving the country to the EE plan implementation. They asked how EE plans took employees' skills and abilities into account. According to a white male participant, individuals should be employed based on skills, ability and knowledge and not based on race or gender. A white male participant from an insurance company highlighted the following:

'It is as if they forgot about skills. Is that not the reason why you employ someone?' (Medical insurer, white, male)

A black male participant was unhappy about being reduced to a 'racial quota'. He would rather have liked to be recognised as a capable, skilled individual and not as a 'black quota employee'. Carrying this role of a 'quota employee', he feels unacknowledged. A black male participant pointed out:

'With the whole EE and AA thing, when a black person gets appointed ... why is it that everyone thinks it is to fill a quota? It is as if we have no skill or education. I went to varsity just like they did! White guys were favoured in the past, and now they are correcting this by discriminating against you ... I was discriminated against when you were not and now I am still being discriminated against!' (Medical insurer, black, male)

Negative stereotypes accompanied the experience of this black participant, who wanted to be viewed as a valued employee with skills and knowledge and not as a person to fulfil a racial quota. Another black male participant contributed that, besides race, gender was a competitive factor in EE:

'Everyone says we should be lucky we are not white and that we have nothing to complain about ... they do not realise that as a black man we have to work just as hard to get a job ... I have applied so many times for a post, just to see a woman get the job ... First, I wasn't white enough, now I'm not the right gender.' (Medical insurer, black, male)

Black males saw themselves as being racially and genderwise discriminated against, while female participants felt stereotyped as 'quota employees', and asked for recognition as skilled employees:

'As a black female employee, I work just as hard and have to go through the same things as men do. It is not like we just get the posts because we are women!' (Medical insurer, black, female)
However, it was not only the gender stereotyping but also the racial stereotyping, and black women generally emphasised the difficulty of building a self-worth on two 'quota' stereotypes, which was counterproductive to the recognition of their 'true' abilities, achievements and knowledge. They saw EE as counterproductive to being recognised for what they really were - valuable employees:

'When you are a woman and you're black, a lot of people think that you are just here because of EE. This decreases one's selfworth.' (black, female)

Black male and female employees wanted to be recognised for their abilities, competences, skills and knowledge and not for their race or gender. White men complained that they were viewed as competent but were left out of EE plans because of their race and gender:

Now imagine how we must feel, being last on the list?' (Motor industry, White, male)

The discourse on EE plans was mainly an issue for black and white employees; mixed race and Indian male and female employees were less involved in the discourse and acted less emotionally on that matter. A female Indian human resource (HR) manager stated:

'In our HR department two skilled black staff members resigned and they were replaced by two white females. Because the HR senior manager is an Indian female and the group head is a coloured male.' (HR manager, Indian, female)

For this HR manager, EE was a support structure to complement skills and abilities according to a racial and gender quota structure, which provided opportunities while managing diversity. Table 3 provides an overview of experiences of EE based on racial and gender group membership.

\section{Theme 2: Experiences of employment equity regarding race and age groups: The 'born-frees'}

Findings showed further that black male and female participants experienced EE as a rather positive tool to create equality, while white participants hardly did so because of the disadvantages they experienced. Participants across racial and gender divides in public and private organisations felt stereotyped based on their racial belonging. White employees classified black employees as 'taking too long to learn' and thereby described them as 'slow' and 'passive' and were critical about black people being able to fulfil their jobs.

TABLE 3: Overview of race and gender experiences.

\begin{tabular}{llll}
\hline Black males & Black females & Indian females & White males \\
\hline $\begin{array}{l}\text { Feel disadvantaged with regard to } \\
\text { female employees in general }\end{array}$ & $\begin{array}{l}\text { Feel discriminated due to being } \\
\text { stereotyped as 'quota } \\
\text { employees' }\end{array}$ & $\begin{array}{l}\text { EE as tool to employ individuals } \\
\text { on racial quota and skills at the } \\
\text { same time }\end{array}$ & $\begin{array}{l}\text { Feel disadvantaged with regard to } \\
\text { black male }\end{array}$ \\
$\begin{array}{l}\text { Feel discriminated due to being } \\
\text { stereotyped as 'quota employees' }\end{array}$ & $\begin{array}{l}\text { Experience stereotyping as black } \\
\text { and female }\end{array}$ & - & $\begin{array}{l}\text { Doel advantaged. Feel } \\
\text { Previously they felt they were } \\
\text { considered black and now are } \\
\text { considered white }\end{array}$ \\
\hline & - & - & $\begin{array}{l}\text { Feel disadvantaged with regard to } \\
\text { female employees in general } \\
\text { Are at the 'end of the line' }\end{array}$ \\
\hline
\end{tabular}

EE, employment equity. 
This critical, negative image of black employees seemed to challenge equal opportunities and equalised work relations, while black employees felt unacknowledged in the $\mathrm{EE}$ racialised system.

How organisations deal with the stereotypes is highly important, because black and white males feel discriminated against by organisations regarding female employees, who have become the main competitors, although they feel reduced to race and gender only:

'I have to work very hard at proving myself so that everyone can see that not only EE is considered in making appointments, but also skills and knowledge.' (black, female)

Participants belonging to the 'born-frees' - individuals who were born post-1991, after the release of Nelson Mandela from prison - contrast with the views of historically disadvantaged South Africans. Born-frees of all races, however, in particular black born-frees, do not define themselves as historically disadvantaged. Therefore, they do not expect special treatment in the workplace in the form of EE and AA. The born-frees just want to be seen as equal, as emphasised by a black female participant:

"As a "born-free" I really think I should not be classified as a historically disadvantaged South African. I want to be treated as an equal to my white counterparts. I may be black, but I come from a privileged background where I have had the blessing to go to private schools.' (Human Resources, black, female)

Born-frees stated that they wanted to be seen as equal across racial membership of groups, because the racial stereotyping, which leads to classifications of advantaged and disadvantaged, is not always right as it does not take the individual's family background into account. They acted against the EEA because of the fact that it is based on a stereotyped view of members of certain racial and gender groups.

A young white male participant took on a different perspective and accepted the collective responsibility constructed in the past:

'Younger white males feel that EE is good. Implemented to redress past inequalities.' (Banking, white, male)

Experiences of EE are determined by race and gender, but also by age. Across all race groups, the younger generation strives to overcome the historical inequalities to transform society in terms of equality and by overcoming categories of (dis)advantage. Table 4 refers to EE experiences by race and age.

\section{Theme 3: Leading and managing diversity through employment equity}

Looking at the question on how to deal with $\mathrm{EE}$ in organisations, leadership is emphasised as one important key. In the banking sector, participants of all races requested a paradigm shift in leadership to deal with the challenges of managing diversity ahead. Participants in the public sector agreed that leaders need to deal with this topic proactively, as one white male manager emphasised:

'Managers should be the drivers of this process, as they are the decision-makers and are ultimately accountable.' (Human Resources, white, male)

Selected black participants were critical of the abilities of senior management to drive EEA processes professionally and constructively. One black female HR manager emphasised:

'Managers feel that it is the responsibility of HR. EE matters
are not of concern to them. We do not have much faith in our
senior and top management to drive this process, as we often
don't trust their decisions around certain appointments and
promotions. They feel that EEA appointments are done to fill
quotas and have nothing to do with the skill of the individual.'
(HR manager, black, female)

A strong competence of leaders to manage diversity within the context of abilities and race was requested by employees; however, they criticised the fact that leaders were not necessarily able to steer this process in a balanced way, and it was emphasised across all groups that leaders need to be trained to manage diversity with regard to the success of the organisation. A white female participant pointed out:

'We used to offer diversity management workshops but were mandated to move toward more functional training and away from the soft skills training, which is judged as being less important.' (Human Resources, white, female)

A white male manager contributed to the discourse that diversity training needs more depth to prepare leaders to manage issues of diversity and take them by their roots:

'Diversity management is done at a very superficial level with an emphasis on trying to be politically correct, but we don't discuss the tough issues as people are reluctant to talk about it. It was felt that there was a need to move away from painting pretty pictures of the "rainbow nation" and deal with these issues.' (Human Resources, white, male)

Male and female white participants highlighted the need to talk openly on diversity issues without avoiding the core problems. Participants saw diversity as a key issue and

TABLE 4: Employment equity experiences by race and age.

\begin{tabular}{|c|c|c|}
\hline Race & Middle and senior employees & $\begin{array}{l}\text { Younger employees/ } \\
\text { born-frees }\end{array}$ \\
\hline $\begin{array}{l}\text { Previously } \\
\text { disadvantaged } \\
\text { employees: } \\
\text { black, mixed } \\
\text { race and Indian }\end{array}$ & $\begin{array}{l}\text { Experiences are based on } \\
\text { categorisations of race and } \\
\text { historical categorisations }\end{array}$ & $\begin{array}{l}\text { Want to be treated as equal } \\
\text { without taking the past into } \\
\text { account and thereby } \\
\text { overcome inequalities and } \\
\text { differences based on } \\
\text { stereotypes and } \\
\text { discrimination }\end{array}$ \\
\hline $\begin{array}{l}\text { Previously } \\
\text { advantaged } \\
\text { employees: } \\
\text { white }\end{array}$ & $\begin{array}{l}\text { Experiences are based on } \\
\text { categorisations of race and } \\
\text { historical categorisations and see } \\
\text { EE as unfair and discriminative } \\
\text { towards the individual who has } \\
\text { to carry collective guilt }\end{array}$ & $\begin{array}{l}\text { Feel that EE is good to } \\
\text { equalise the differences } \\
\text { created during Apartheid. } \\
\text { Want to see everybody } \\
\text { equal }\end{array}$ \\
\hline
\end{tabular}

$\mathrm{EE}$, employment equity. 
maybe even a taboo that required political correctness and openness to move beyond the accepted discourses to transform the challenges into solutions. Leaders can create awareness through EE policies beyond the personal involvement of employees, highlighted a black female manager:

'People think of their own colour when positions are advertised. Race is always a necessary option when considering filling position and certain races are more entitled to obtain employment.' (Manager, black, female)

Black participants judged EE as positive, while white employees saw EE as being used by leaders as a tool to segregate and exclude white people from workplace competition. A white male manager stated:

'Employment equity policies are literally pushing white people out of the workforce.' (, white, male)

A black female HR manager criticised the fact that the EEA demands both public and private employers to meet certain equity targets but, however, they do not succeed on all levels:

'Organisations rely excessively on the numbers game in that EE requirements are applied with diligence when appointments are made for junior and mid-tier employees while these proportions are clearly not replicated in top management structures across the organisation.' (HR manager, black, female)

This statement reflects the frustration of male and female black participants that the EE targets have not been reached in top management, resulting in a negative view of EE.

\section{Theme 4: Talent management}

Further, EE was discussed in the context of talent management and the questions of how to train and foster talent. A white male participant in an insurance company highlighted:

'We are training people just to comply with statistics. There is no follow-through to see the impact of the training and too much of it is theoretical and not practical in nature. There is no succession planning, because we are always recruiting externally. My skill as forensic auditor is very rare and dominated by white expolicemen. Why don't we groom our black brothers? Obviously, we would look at people that are currently doing well in their roles.' (Human Resources, white, male)

This highly skilled white male participant criticised the training and development concepts within the organisation as being unsustainable and as being short-sighted. He further on suggested that there be a focus on developing black internal employees with talent within the organisation, before recruiting externals. Talent management in organisations is promoted through specific learning opportunities. However, a white male employee criticised the fact that the opportunities for competencies, growth and self-development were not linked to promotion for him because of EE:

'I know that I am good at what I do, and so do the managers. I can promise you now, if a manager's post become vacant,
I would be the last person to get that post. So I don't see myself going anywhere fast.' (Medical insurer, white, male)

The participant felt that EE hindered him from moving forward with regard to his promotion. He was frustrated with the EE processes and he could not see his development in the future within the organisation. Mentorship in organisations was perceived as being positive to develop individuals, as a black male employee in an insurance company emphasised, to support juniors to develop and learn:

'The last mentor I had was my ex-manager. We just clicked, and he started teaching me and that worked, because I am now a team leader. This was not a formalised process. Some managers will mentor people from previously disadvantaged groups, because they understand the importance of diversity.' (Human Resources, Black, male)

This participant clearly stated that mentoring was not based on a specific mentoring programme and EE plans but on the personal view of the leader on diversity within the organisation. In his case, the mentor-mentee relationship was based on personal sympathy and an interest of the leader in creating a diverse organisation, which then led to developing the participant's talent further as well as his chances to be promoted.

An Indian male participant in the same organisation also experienced training and development negatively:

'The only thing they do is to offer the bursaries and then afterwards they do not give you the opportunity to practise what you have learned. Why doesn't the company want return on its investment? For some reason people from previously disadvantaged groups are grabbing the learning opportunity because they think studying will increase their chances of moving upwards - but this is not the case.' (Human Resources, Indian, male)

This Indian male participant also highlighted the fact that talent management programmes, such as bursaries, were in place, but participating did not necessarily lead to promotion within the organisation, which was strongly criticised. Generally, participants were aware of different talent management options. However, they criticised the fact that there was a lack of transparency: how the participation in talent management programmes leads to promotion and who is promoted is not defined on talent only but also on other criteria, such as race.

\section{Theme 5: Tokenism}

The findings show 23 statements that EE and tokenism is viewed as being misused rather than positively used within organisations. A black male participant from an insurance company emphasised:

'If you look at my team, I am sure I was appointed as the token black. I actually don't care - at least I was able to get a job. Now I can prove myself.' (Medical insurer, Black, male)

This male black participant was conscious and reflective with regard to why he had been employed and he believed he was 
employed as a 'token'. However, he did not let this idea frustrate him but rather used his opportunity to prove himself. However, two black females were strongly frustrated by the tokenism they experienced. One of them pointed out:

'We are all professionals in our own right, and we all compete for jobs; when I go into an interview I give it my all, just like everyone else. It really hurts when one is working so hard on a career, and when you think the hard work paid off, someone says: "You were only appointed due to colour".' (Medical insurer, Black, male)

This participant was highly frustrated about being reduced to her skin colour and being unacknowledged with regard to her competences, as one of her colleagues also explained:

'When will we ever be good enough like them [non-previously disadvantaged]? By saying I am a token appointee, you basically say that you think I don't deserve it, because I'm not qualified, what a nerve!' (Medical insurer, black, female)

She expressed her anger about being stereotyped as unskilled and appointed only because of racial background. The entire discourse around tokenism was mainly led by male and female participants, based on their frustration and anger at being labelled as unskilled. While one male black participant saw this as a chance to prove himself, the female black participant felt strongly frustrated and angry and did not view this as a starting point to prove herself.

\section{Discussion}

As Oosthuizen and Naidoo (2010) have pointed out, the research shows that EE plans are strongly entangled into the discourse of race and gender and the experience of perceived reverse discrimination. The findings indicate that the white male participants seemed the least satisfied with the EE plans. They did not see EE as a fair and non-biased employment plan (Bendix, 2010); however, individuals of all groups experienced the EE plan as biased and a method to heighten the focus on racial divides, as described by the Council for Higher Education (2015).

The study supports the idea that active transformation is needed (Van der Westhuizen, 2015) and that changes seem to rather stay 'on the surface' (Herman, 2017), not reaching the depth required with regard to soft skill training for EE. The participants agreed that transformation is slow (Breetzke \& Hedding, 2016); however, they did not share the view of Zulu and Parumasur (2009) that EE is non-existent. They rather felt that EE consists of complexities and failures (Burger et al., 2016) in individuals' response to EE (Lee, 2016). Employment equity movements are not always viewed as positive (as in Ivona \& Lance, 2014). Participants experience EE negatively when it comes to self-image with regard to racial and gender stereotyping, as well as tokenism and stigmatisation (Heilman, Black, \& Stathatos, 1997; Ivona \& Lance, 2014). White participants fear retribution or revenge from members of previously disadvantaged groups, loss of standards, punitive taxation and limitation of their career opportunities (De Beer \& Radley, 2000; Leonard \& Grobler, 2006). Black participants see themselves as being labelled as incompetent and unskilled (Heilman et al., 1997) - findings supported in this study (Golele \& Rachidi, 2017). White male participants highlight the fact that they feel excluded from professional recruitment processes or are released from positions, while black participants feel stereotyped as unskilled and employed because of race only. This is the reason that born-frees of all groups vote for overcoming $\mathrm{EE}$ and employment in the context of racial categorisation.

According to Segalo (2014), born-free individuals do not expect special treatment in the workplace through EE and AA - substantiated by the younger generation in this study. Challenges arise within organisations where, in the implementation of EE and with the drive to meet legislative quotas, white males are deliberately excluded from recruitment and development opportunities (in this study as in Segalo, 2014).

Roman and Mason (2015) indicate that EE tends to be racially and numbers-driven at the expense of competence, as presented in these findings. Further, members of previously disadvantaged groups seem to foster their education through bursaries, diversity management and personal mentorship but are often not promoted although they have increased their education. They experience EE implementations as comparably slow and perceive that EE training is not addressed with enough depth (Roman \& Mason, 2015). This is reflected in the call for recruitment, promotion in organisations (through further education), diversity management strategies and personal mentorship; however, all of these aspects are rather random and are not implemented based on more complex management strategies.

The individual differences in the way various employees respond to the idea of tokenism seems to suggest that selfimage threats are mitigated through self-affirmation tasks (Ivona \& Lance, 2014). The experiences and perceptions of the employees seem to corroborate Ivona and Lance's (2014) studies on self-enhancement that self-interest accounts for beneficiaries of EE reacting negatively to EE policies in the same manner as non-beneficiaries react. Black employees emphasise the fact that they reject being taken as a token. However, there is a difference in the way male and female black employees manage tokenism: male employees seem to take it as the start of their competitive behaviour, while female black employees feel frustrated and angered by the treatment.

The current EEA landscape includes gender discrimination in addition to race discrimination (Denton Vloeberghs, 2003; Ng \& Burke, 2004; Oosthuizen \& Naidoo, 2010). This study supports the previous findings of Zulu and Parumasur (2009) and highlights the fact that, in senior management transformation, processes seem to be rather slow. Furthermore, employees do not believe that their companies have done enough to employ and promote previously disadvantaged groups as envisaged in labour legislation (Thaver, 2010). 
Zulu and Parumasur (2009) emphasise the fact that without viable structures or systems, such as transformation forums, mentorship programmes and human resources policies to support the integration of previously disadvantaged groups into corporate environments, no transformation effort will yield results and the effective management of cultural diversity will not be realised. Diversity management needs to become a structured organisational process, otherwise organisations will ultimately have to deal with job hopping particularly of black employees, culture clashes, stifling corporate cultures and hostile environments (Ngobeni, 2006). According to Moses (2006, p. 6), women are alienated from 'testosterone-fuelled corporate cultures' and individuals are not enabled and empowered (Ntuli, 2006). The findings also show that no structured diversity management is provided in organisations and that it therefore stays superficial, personalised and rather ineffective. Both Leonard and Grobler (2006) and employees in this study suggest that communication of the purpose and transformation within the entire workforce is needed.

A study conducted by Preeya (2014) indicates that key inclusion elements that need to be transformed at an organisational level include, among others, senior leadership, communication and transparent recruitment, promotion and development. At an interpersonal level engagement is needed, which includes decision-making authority and access to information (Preeya, 2014). This study also highlights the fact that senior management needs to take on responsibility in the $\mathrm{EE}$ processes and make decisions accordingly with regard to recruitment processes. Generally, the findings support the view that leadership must be strong to manage EE well across racial divides (Mayer, 2017).

\section{Recommendations}

This research study calls for comparative research in terms of how EEA is implemented in South Africa and in other countries. Thereby, positive experiences in the EE processes could increasingly be taken into account. Best practices of EE should be evaluated with regard to meso- and micro-levels in organisational management.

On a practical level, findings can be used by human resources managers to: (1) monitor the progress towards EE competently and vigorously, (2) create awareness and communication within individuals, organisations and society regarding EE, (3) create best practices in order to benefit from EE (members of all racial, gender, cultural groups), (4) create a discourse on humanistic and reflexive human resources management (Mahadevan \& Mayer, 2017) and (5) implement consulting, training and development programmes in organisations that are strategically, sustainably and long-term orientated.

\section{Conclusion}

The aim of this article was to present voices from individuals of diverse cultural, racial, gender and age groups working in South African organisations. Findings show that EE experiences are connected to racial, gender and age group memberships; individuals experience $\mathrm{EE}$ as heightening racial discrimination and stereotyping with regard to specific race groups. While white employees experience EE as reverse racism, black employees see it rather as an attempt to create equal access to the labour market for all individuals. Both black and white males feel discriminated against by female competitors. Born-frees do not want to return to previous (historical) categorisations, racial discrimination and advantages and stand up for equality.

Further, many employees across race and gender groups describe that they suffer stereotyping because of EE. They are of the opinion that diversity management is needed but that organisations do not focus enough on managing diversity effectively through organisational strategies. Diversity management is viewed as a superficial attempt to overcome racial challenges, and employees across the board request stronger leadership in EE contexts.

\section{Acknowledgements}

The authors would like to thank the organisations and individual employees for participating in this study.

\section{Competing interests}

The authors declare that they have no financial or personal relationships that may have inappropriately influenced them in writing this article.

\section{Authors' contributions}

R.O. conceptualised the study and wrote the first draft. L.T. and C.M. did the data analysis. All authors reviewed and approved the final manuscript.

\section{References}

Basson, Y. (2017). Selected developments in South African labour legislation related to persons with disabilities. PER / PEL, 20, 2-21. http://doi.org/10.17159/17273781/2017/v20i0a1216

Bendix, S. (2010). Industrial relations in South Africa. (5th edn.). Cape Town: Juta.

Booysen, L. (2007). Barriers to employment equity implementation and retention of blacks in management in South Africa. Southern African Journal of Labour Relations, 31(1), 47-71.

Breetzke, G. D., \& Hedding, D. W. (2016). The changing racial profile of academic staff at South African Higher Education Institutions (HEIs), 2005-2013. Africa Education Review, 13(2), 147-164. https://doi.org/10.1080/18146627.2016.1224114

Burger, R., Jafta, R., \& Von Fintel, D. (2016). Affirmative action policies and the evolution of post-apartheid South Africa's racial wage gap, WIDER Working Paper, No. 2016/66, ISBN 978-92-9256-109-3.

Coetzer, N. (2009). Affirmative action: The sword versus shield debate continues. SA Mercantile Law Journal, 21, 92-101.

Council for Higher Education (CHE). (2015). Annual report 2014/2015. Council on Higher Education. Retrieved from http://www.che.ac.za/sites/default/files/ publications/CHE\%20Annual $\% 2$ Report $\% 20$ of $\% 20$ the $\% 20$ Council $\% 20$ on $\% 20$ Higher\%20Education.pdf

Clarke, S., \& Hogget, P. (2009). Researching below the surface. Psycho-social research methods in practice. London: Karnac.

Cloete, N., Bunting, I., \& Maassen, P. (2015). Research universities in Africa: An empirical overview of eight flagship universities. In N. Cloete, P. Maassen, \& $\mathrm{T}$. Bailey (Eds.), Knowledge production and contradictory functions in African higher education (pp. 18-31). Cape Town: African Minds.

Collins, J., \& Hussey, R. (2014). Business research: A practical guide for undergraduate and postgraduate students. New York: Palgrave Macmillan Higher Education. ISBN: 978-0-230-30183-2. 
Creswell, J. W. (2013). Qualitative inquiry \& research: Choosing among five approaches (3rd edn.). London: Sage Publications.

Creswell, J. W., \& Plano Clark, V., (2011). Designing and conducting mixed methods research (2nd edn.). London: Sage Publications.

De Beer, J. J., \& Radley, J. H. (2000). A case for managing diversity. Georgeville, MN Enza.

Denton, M., \& Vloeberghs, D. (2003). Leadership challenges for organizations in the New South Africa. Leadership and Organization Development Journal, 24(2), 84-95. https://doi.org/10.1108/01437730310463279

Department of Labour. (1998). Employment equity act, No. 55 of 1998. Retrieved from http://www.labour.gov.za

Department of Labour. (2002). Employment equity register. Retrieved from http:// www.labour.gov.za/documents/usefuldocuments/employmentequity/ www.labour.gov.za/documents/usefuldocuments/employmentequity/ downloads/Useful\%20Docum
Equity\%20Registry\%202002.pdf

Dilthey, W. (2002). The formation of the historical world in the human sciences. In R. A. Makkreel \& F. Rodi (Eds.), Wilhelm Dilthey selected works (Vol. 3). Princeton, NJ: Princeton University Press.

Dingindawo, N., Nwafor, A., Mutshaeni, N., Mudzielwana, N., \& Mulovhedzi, S. (2016). Redressing past injustices through affirmative action: Creating opportunities for women to assume leadership positions in the society. Journal of Educational Studies, 15(2), 180-196.

Ebrahim, S. (2018). Reviewing the suitability of affirmative action and the inherent requirements of the job as grounds of justification to equal pay claims in terms of the employment equity act 55 of 1998 . PER / PELJ, 21, 2-38.

Employment Equity Act 55. (1998). Pretoria: Government Printer.

Fernandez, S. (2016). The transformation of the South African public service: Exploring the impact of racial and gender representation on organisational effectiveness. Journal of Modern African Studies, 54(1), 91-116. https://doi.org/10.1017/ S0022278X15000816

Golele, F. H., \& Rachidi, M. (2017). The challenges of achieving gender equity in a government department: A case study of the department of health, Limpopo Province, South Africa. Gender \& Behaviour, 15(3), 9584-9606.

Government Gazette. (2014). Employment equity act (55/1998): As amended: Draft employment equity regulations, 2014. Regulation Gazette, 10127(584), Pretoria,
28 February 2014, No. 37338 Labour Department of Government Notice R. 124.

Grix, J. (2010). The foundations of research (2nd edn.). Chippenham, Eastbourne: Palgrave and Macmillan, CPI Antony Rowe. ISBN 978-0-230-24897-7.

Hassan, I., \& Ghauri, P. N. (2014). Evaluating companies for mergers and acquisitions. Book series: International Business and Management (Vol. 40, pp. 75-89). Bingley, England: Emerald.

Heilman, M. E., Block, C. J., \& Stathatos, P. (1997). The affirmative action stigma of incompetence: Effects of performance information ambiguity. Academy of Management Journal, 40(3), 603-625.

Herman, H. D. (2017). Affirmative action in education and black economic empowerment in the workplace in South Africa since 1994: Policies, strengths and limitations. BCES Conference Books, 15. Sofia: Bulgarian comparative education society. ISSN 1314-4693 (print), ISSN 2534-8426 (online), ISBN 978-619-7326-000 (print), ISBN 978-619-7326-01-7 (online).

Hills, J. (2015). Addressing gender quotas in South Africa: Women empowerment and gender equality legislation. Deakin Law Review, 20(1), 153-184. https://doi. org/10.21153/dlr2015vol20no1art498

Ivona, H., \& Lance, F. D. (2014). Support for employment equity policies: A selfenhancement approach. Organizational Behavior and Human Decision Processes, 123(1), 49-58. https://doi.org/10.1016/j.obhdp.2013.11.002

Kafle, N. (2013). Hermeneutic phenomenological research method simplified. Bodhi: An Interdisciplinary Journal, 5, 181-200.

Kruger, D. (1988). An introduction to phenomenological psychology. (2nd edn.). Cape Town: Juta.

Lee, H. A. (2016). Affirmative action regime formation in Malaysia and South Africa. Journal of Asian and African Studies, 51(5), 511-527. https://doi. org/10.1177/0021909614550895

Leonard, A., \& Grobler, A. F. (2006). Exploring challenge to transformational leadership communication about employment equity: Managing organizational change in South Africa. Journal of Communication Management, 10(4), 390-406. https:// doi.org/10.1108/13632540610714827

Lincoln, Y. S., \& Guba, E. G. (1985). Naturalistic inquiry. Beverly Hills, CA: Sage.

Louw, A. M. (2015a). I am not a number! I am a free man! The employment equity act, 1998 (and other myths about the pursuit of 'equality', 'equity' and 'dignity' in post-apartheid South Africa) Part 1. P.E.R, 18(3), 668-735. http://doi.org/10.4314/ pelj.v18i3.05

Louw, A. M. (2015b). I am not a number! I am a free man! The employment equity act, 1998 (and other myths about the pursuit of 'equality', 'equity' and 'dignity' in post-apartheid South Africa) Part 2. P.E.R, 18(3), 668-735.

Mahadevan, J., \& Mayer, C.-H. (2017). Muslim minorities, workplace diversity and reflexive HRM. New York: Routledge.

Maharaj, K., Ortlepp, K., \& Stacey, A. (2008). Psychological contracts and employment equity practices. Management Dynamics, 17(1), 16-30.

Masombuka, S. (2016). Varsities down on women, (2016, March 22) Times Lives.

Mason, G., Williams, G., \& Cranner, S. (2009). Employability skills initiatives in higher education: What effects do they have on graduate labour outcomes? Education Economics, 17(1), 1. https://doi.org/10.1080/09645290802028315
Mayer, C.-H. (2017). A 'derailed' agenda? Black women's voices on workplace transformation. Journal of International Women's Studies, 18(4), 144-163.

Mayer, C.-H., \& Barnard, A. (2015). Balancing the scales of gender and culture in contemporary South Africa. In S. Safdar \& N. Kosakowska-Berezecka (Eds.), The psychology of gender and culture (pp. 327-352). New York: Springer.

Moraka, N. V., \& Jansen van Rensburg, M. (2015). Transformation in the South African mining industry - Looking beyond the employment equity scorecard. The Journa of the Southern African Institute of Mining and Metallurgy, 115, 669-678. http:// doi.org/10.17159/2411-9717/2015/v115n8a2

Moses, B. (2006). Glass ceiling not to blame: Women alienated by male corporate culture. City Press.

Nel, P. S., Kirsten, M., Swanepoel, B. J., Erasmus, B. J., \& Poisat, P. (2008). South African employment relations theory and practice (6th edn.). Pretoria: Van Schaik.

Nel, P. S., Kirsten, M., Swanepoel, B. J., Erasmus, B. J., \& Poisat, P. (2012). South African employment relations theory and practice (7th edn.). Pretoria: Van Schaik.

Nel, P. S., Kirsten, M., Swanepoel, B. J., Erasmus, B. J., \& Poisat, P. (2016). South African employment relations theory and practice (8th edn.). Pretoria: Van Schaik.

Nevin, T. (2008). Chinese are now black - Official. African Business, August/September, 28-29.

Ng, E. S. W., \& Burke, R. J. (2004). Cultural values as predictors of attitudes towards equality and diversity: A Canadian experience. Woman in Management Review, 19(6), 317-324. https://doi.org/10.1108/09649420410555088

Ngobeni, M. (2006). Black job-hopping not all about the money. Sunday Times, Business Times, p. 8.

Nicoll, B. (2006). The rewards eight years later. People Dynamics, 24(3), 6-7.

Ntuli, D. (2006). Do you fit in? Career Junction. Retrieved from http://ananzi. careerjunction.co.za

Op't Hoog, C., Siebers, H., \& Linde, B. (2010). Affirmed identities? The experience of black middle managers dealing with affirmative action and equal opportunity policies at a South African mine. South African Journal of Labour Relations, 34(2), 60-83.

Oosthuizen, R. M., \& Naidoo, V. (2010). Attitudes towards and experience of employment equity. SA Journal of Industrial Psychology, 36(1), Art. \#836, 1-11. https://doi.org/10.4102/sajip.v36i1.836

Pietersen, C. (2007). Interpersonal bullying behaviours in the workplace. South African Journal of Industrial Psychology, 33(1), 59-66. https://doi.org/10.4102/sajip. v33i1.256

Portnoi, L. M. (2003). Implications of the employment equity act for the higher education sector. South African Journal of Higher Education, 17(2), 79-85.

Preeya, D. (2014). Diversity and inclusion in an emerging market context. An International Journal Equality, Diversity and Inclusion, 33(3), 293-308. http://doi. International Journal Equality, Dive
org/10.1108/EDI-10-2012-0087

Ramgoolam, S. (2005). Experiences of employment equity in the coal mining industry. (Unpublished master's dissertation). University of South Africa, Pretoria.

Rautenbach, I. M. (2015). Requirements for affirmative action and requirements for the limitation of rights. South African police service $v$ solidarity obo RM Barnard 201410 BCLR 1195. TSAR, 2, 432-443.

Reuben, S., \& Bobat, S. (2014). Constructing racial hierarchies of skill - Experiencing affirmative action in a South African organisation: A qualitative review. SA Journa of Industrial Psychology/SA Tydskrif vir Bedryfsielkunde, 40(1), Art. \#1158, 12 pages. http://doi.org/10.4102/sajip.v40i1.1158

Roman, L. J., \& Mason, R. B. (2015). Employment equity in the South African retail sector: Legal versus competence and business imperatives. South African Journal of Labour Relations, 39(2), 84-104.

Saha, S. K, O'Donnell, D., Patel, T., \& Henegehan, J. (2008). A study of individual values and employment equity in Canada, France and Ireland. Equal Opportunities International, 27(7), 629-645. https://doi.org/10.1108/02610150810904328

Sebola, M. S., \& Khalo, T. (2010). Implementation of employment equity: A case of the Universities of Venda and of Pretoria. Journal of Public Administration, 45 202-217.

Segalo, N. R. (2014). A qualitative study on the opinions, attitudes and experience of employment equity for various racial groups in an organisation's Human Resources employment equity for various racial groups in an organisation's Human Resources departmentia.
Pretoria.

Stoffels, M. C. (2015). Evaluering van Regstellende Aksie in konteks van moontlike onbillike diskriminasie teen subgroepe binne die aangewese groep. PER/PELJ, 18(5), 1954-1977. http://doi.org/10.4314/pelj.v18i5.24

Surtee, S., \& Hall, M. (2009). Transformation: African people in the Western Cape. Commissioned by the Development Policy Research Unit. Cape Town: University of Cape Town.

Thaver, B. (2010). The transition to equity in South African higher education: Governance, fairness, and trust in everyday academic practice. International Journal of Politics, Culture, and Society, 23(1), 43-56. https://doi.org/10.1007/ s10767-010-9098-0

Thomas, A. (2002). Employment equity in South Africa: Lessons from the global school. International Journal of Manpower, 23(3), 237-255. https://doi org/10.1108/01437720210432211

Timothy, O. (2013). Affirmative action: The uncertainty continues. People Dynamics, 13(9), 3-5.

Van der Westhuizen, E. J. (2015). Democratisation of employment in the public sector. A constitutional perspective grounded in the interpretation of litigated cases between 1996 and 2013. Politeia, 34(2), 597777. ISSN 0256-884. 
Van Zyl, B. (2017). Affirmative Action in SAPS. hrfuture.net, 12, 38-43.

Warnich, S., Carell, M. R., Elbert, N. F., \& Hatfield, R. D. (2015). Human resource management in South Africa. (5th edn.). Hampshire: Cengage Learning EMEA.

Welman, C., Kruger, F., \& Mitchell, B. (2012). Research methodology. OUP Southern Africa. ISBN 0195789016, 9780195789010.

Yin, R. K. (2009). Case study research design and methods (4th edn.) Thousand Oaks, CA: Sage.
Zach, L. (2006). Using a multiple-case studies design to investigate the informationseeking behavior of arts administrators. Library Trends, 55(1), 4-21. https://doi. org/10.1353/lib.2006.0055

Zulu, P. S., \& Parumasur, S. B. (2009). Employee perceptions of the management of cultural diversity and workplace transformation. South African Journal of Industrial Psychology, 35(1), Art. \#426, 9 pages. http://doi.10.4102/sajip. v35i1.426 